\title{
INFLUENCE OF THE LOAD DISTRIBUTION AND SIZES ON THE WHEEL GEOMETRY IN PASSENGER CARS
}

\author{
Jarosław Gonera*, Jerzy Napiórkowski, Kamil Ciborowski \\ Department of Vehicle and Machine Construction and Operation, University of Warmia and Mazury in Olsztyn, \\ Olsztyn, Poland \\ *E-mail of corresponding author: jaroslaw.gonera@uwm.edu.pl
}

\begin{abstract}
Resume
This paper discusses impact of changes in the load size and distribution in passenger cars on geometry of the suspension and steering systems. It was found to have a major impact on the road safety. The research was carried out with the four most popular suspension system designs used in modern passenger cars, i.e. multi-link suspension on both front and rear axles, only on the front axle, only on the rear axle and a simple suspension design for both front and rear axles. Eight load variants were used for the tests. Changes in the following wheel geometry parameters were identified: toe-in and camber angles of all the wheels and castors for the front wheels. The numerical relationships were determined between the load distribution and sizes and changes in suspension and steering systems in passenger cars. It was found that cars with multi-link suspension in both front and rear axles adapt best to changes in weight and load distribution.
\end{abstract}

Available online: https://doi.org/10.26552/com.C.2021.1.B1-B12

\section{Article info}

Received 23 January 2020

Accepted 11 June 2020

Online 21 October 2020

\section{Keywords:}

wheel geometry, suspension, simulated weight and load distributions, cars

ISSN 1335-4205 (print version) ISSN 2585-7878 (online version)

\section{Introduction}

In modern vehicles, manufacturers have introduced numerous changes in design, which contributed to an increase in safety during their operation [1-3]. For modern cars intended to provide good performance to drivers, it is necessary to introduce more safety systems and more advanced structures of suspension and steering systems, which improve driving quality and greatly reduce the risk of accidents [4-6]. It is a common belief that the active safety is related to design of the suspension and steering systems, which provide the possibility of a quick and precise response to prevent occurrence of an accident or a road collision [7-11]. It should be stressed that quite often such factors are listed as having an impact on the active safety of a vehicle along with the technical conditions of the suspension and steering systems and, above all, their correct mounting and alignment, appropriate traction properties and optimal load distribution between the axles, [12-13]. Changes in geometry of the suspension and steering systems reduce a vehicle's stability and may cause problems with controlling the vehicle and maintaining the driving track assumed by the driver under the influence of varied disturbances affecting the vehicle [13-15].

During the vehicle operation, various forces and moments, resulting from traffic conditions, are transferred to vehicle suspension and steering systems, as well as to its body. Those are related to interaction of forces and moments resulting from unavoidable environmental conditions, such as the condition of the road surface, kerbs, etc. [16]. A car is a complex system, which is subjected to influence of varied dynamic forces and environmental conditions with a wide frequency range [17]. The literature distinguishes two main types of loads acting on a vehicle: static and dynamic [1819]. In the first case, they are related to loading of the car body with a torsional moment, resulting from application of forces from the suspension system, from the surface and the bending moment, resulting from the weight of the vehicles, driver, passengers and transported load. In the latter case, however, they are result of conditions related to the speed and acceleration of the car, as well as the conditions acting on a vehicle when taking a turn, driving on bumps, braking and accelerating [18-20].

The structural changes in contemporary suspension systems are mainly aimed at improving the comfort of the driver and passengers and at improving the precision of driving [21-23]. The suspension system of a modern vehicle largely reduces the forces, reaction forces and vibrations transmitted to the car body from the road [24-25]. The issue of changes in the wheel geometry, depending on the load, was discussed in [26-27]. It was found that in the suspension systems with a simpler and less complex design (e.g. McPherson's column, torsion-beam axle), parameters affecting stiffness and responsible for control of a vehicle (e.g. toe-in, castor) are subject to significant changes depending on the changing load conditions. This limits precise vehicle control and stability during driving. The resulting changes in the wheel geometry may also 
Table 1 Characteristics of the research object

\begin{tabular}{ccc}
\hline model & front axle suspension type & rear-axle suspension type \\
\hline A1 & independent - McPherson & independent - multi-link \\
A2 & independent - McPherson & independent - multi-link \\
B3 & independent - McPherson & semi-dependent - with torsional beam \\
B4 & independent - McPherson & semi-dependent - with torsional beam \\
C5 & independent - multi-link & semi-dependent - with torsional beam \\
C6 & independent - multi-link & semi-dependent - with torsional beam \\
D7 & independent - multi-link & independent - multi-link \\
D8 & independent - multi-link & independent - multi-link
\end{tabular}

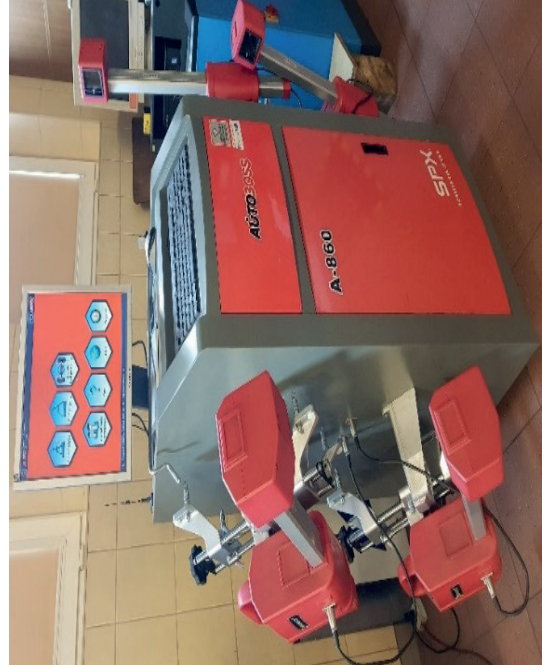

a)

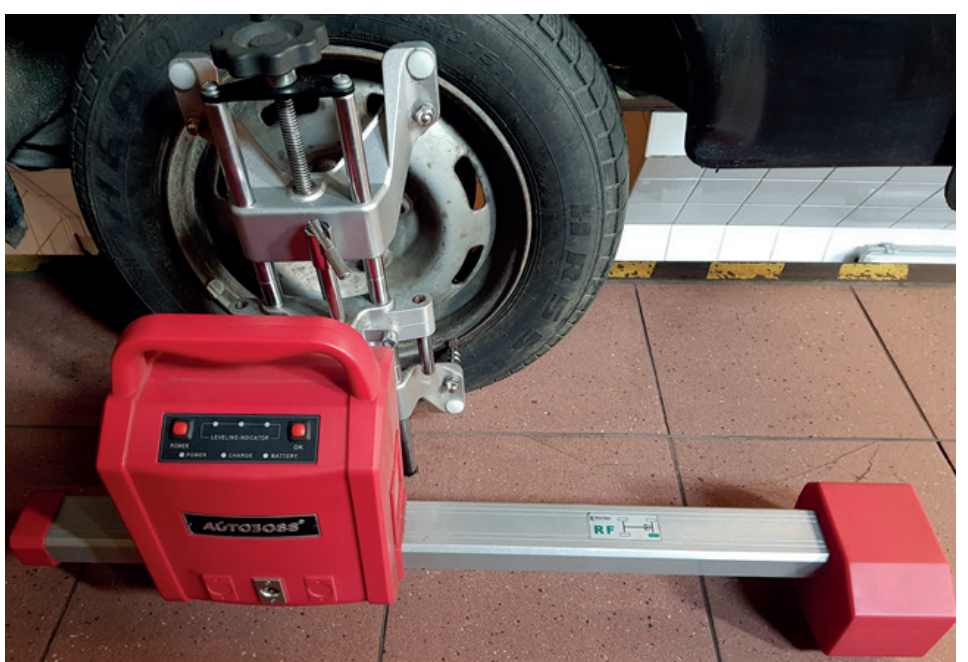

b)

Figure 1 Autoboss A860: a. control unit with heads; b. measuring head mounted on a wheel

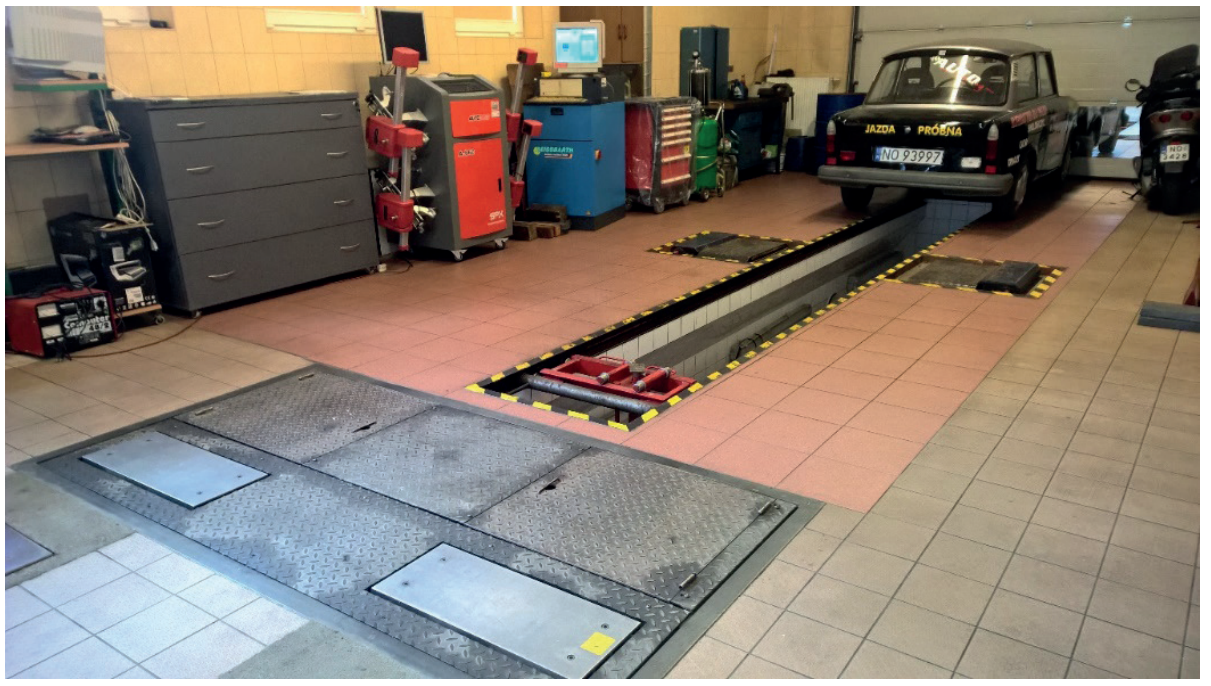

Figure 2 Beissbarth STL7000 diagnostic line

contribute to higher tyre wear [28]. Unfortunately, there are still no construction solutions to guarantee driving steering with changes in the load sizes and distribution [21, 23-24, 27].

This study analysed impact of changes in size and distribution of the load in a passenger car on parameters of the wheel geometry in vehicles with different suspension system designs.

\section{The test procedure}

The study was carried out on passenger cars characterized by varied structure of the front and the suspension system of a rear axle. All of the vehicles were equipped with a rack and pinion steering gear with power steering. This solution is present in most modern passenger cars. The tested vehicles had similar weight and external 


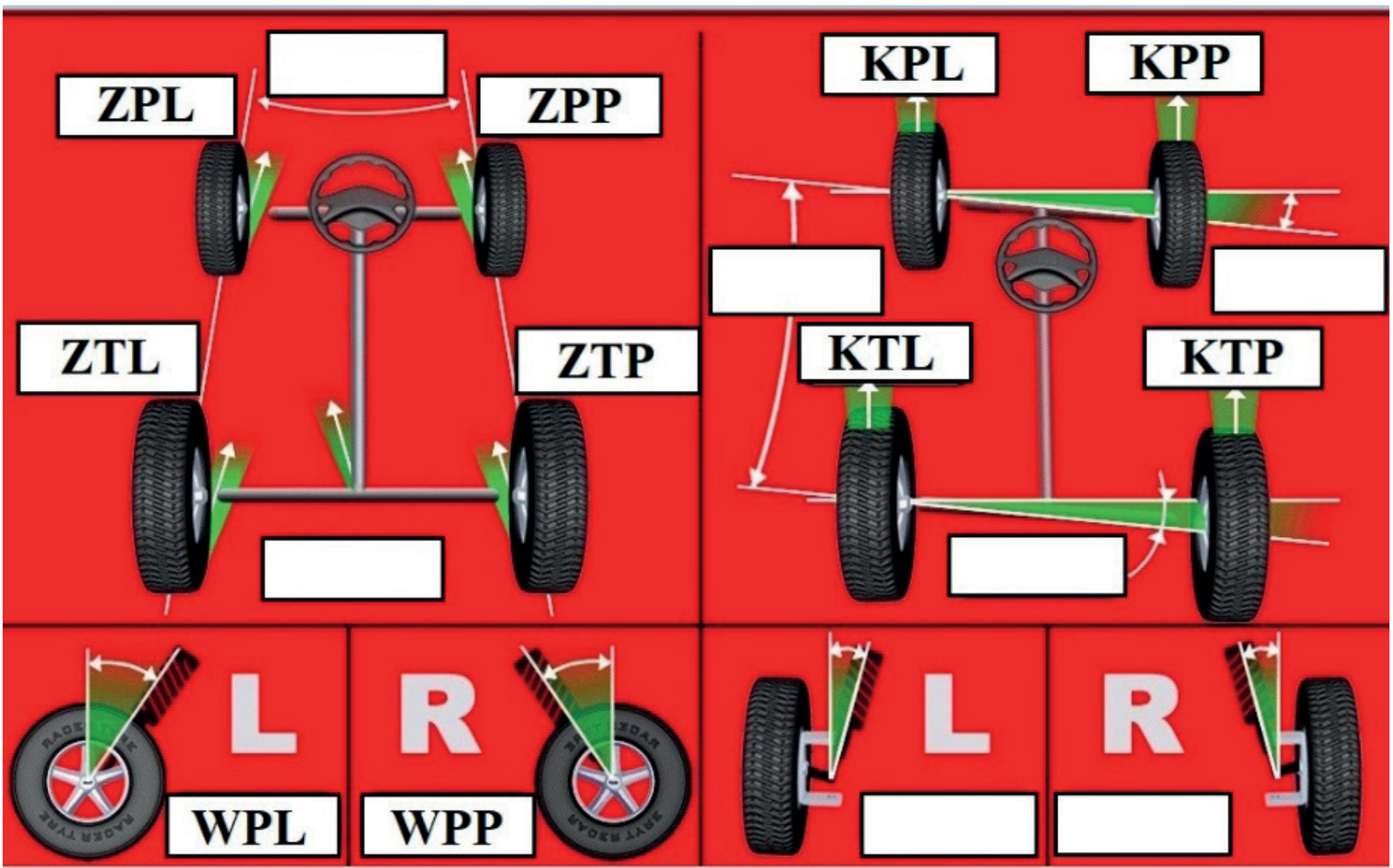

Figure 3 Parameters related to wheel geometry: ZPL- toe-in for the left front axle wheel; ZPP - toe-in for the right front axle wheel; KPL - camber for the left front axle wheel; KPP - camber for the right front axle wheel; WPL - castor for the left front axle wheel; WPP - castor for the right front axle wheel; ZTL - toe-in for the left back axle wheel; ZTP - toe-in for the right back axle wheel; KTL - camber for the left back axle wheel; KTP - camber for the right back axle wheel

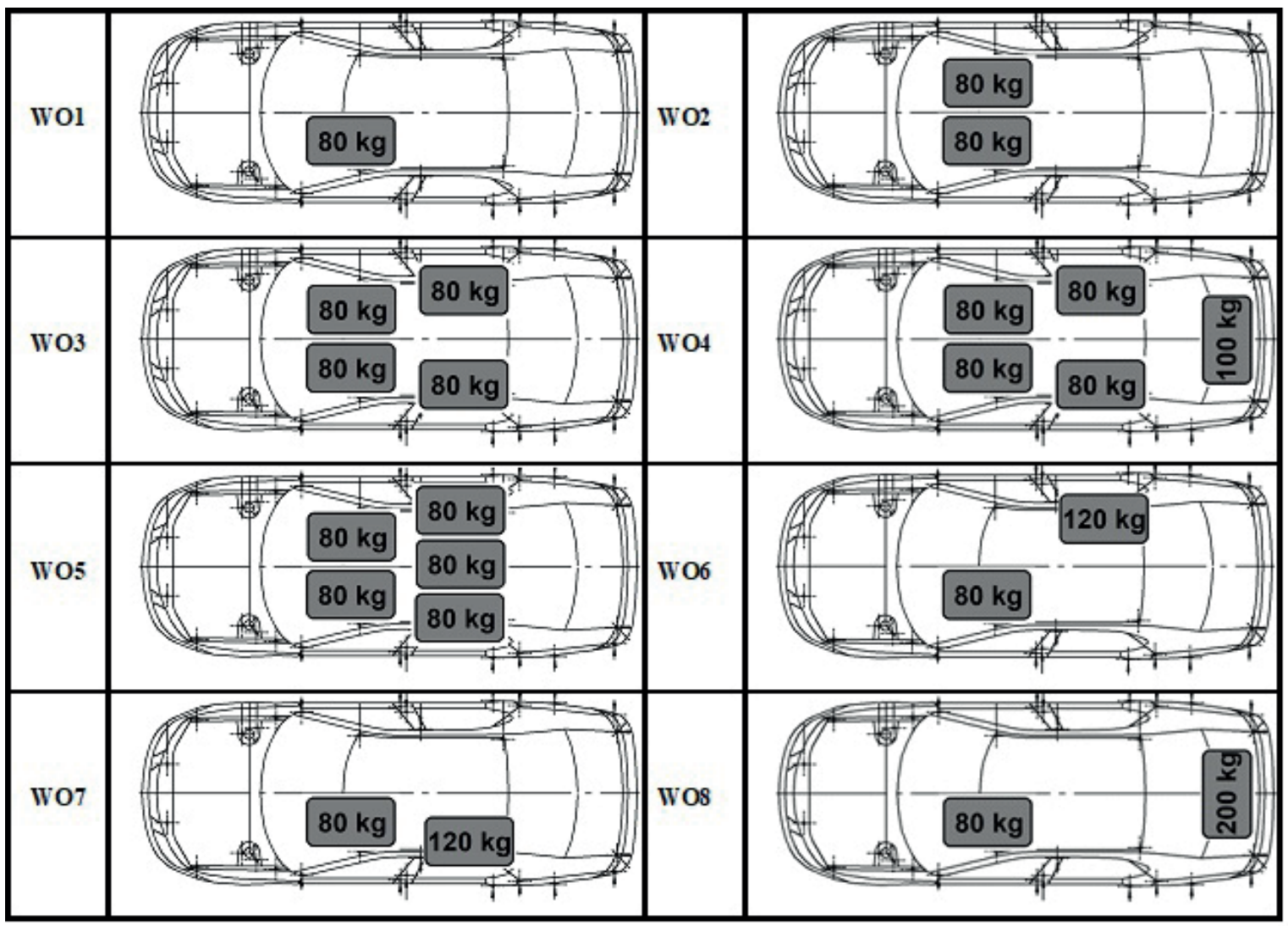

Figure 4 Simulated weight and load distributions 


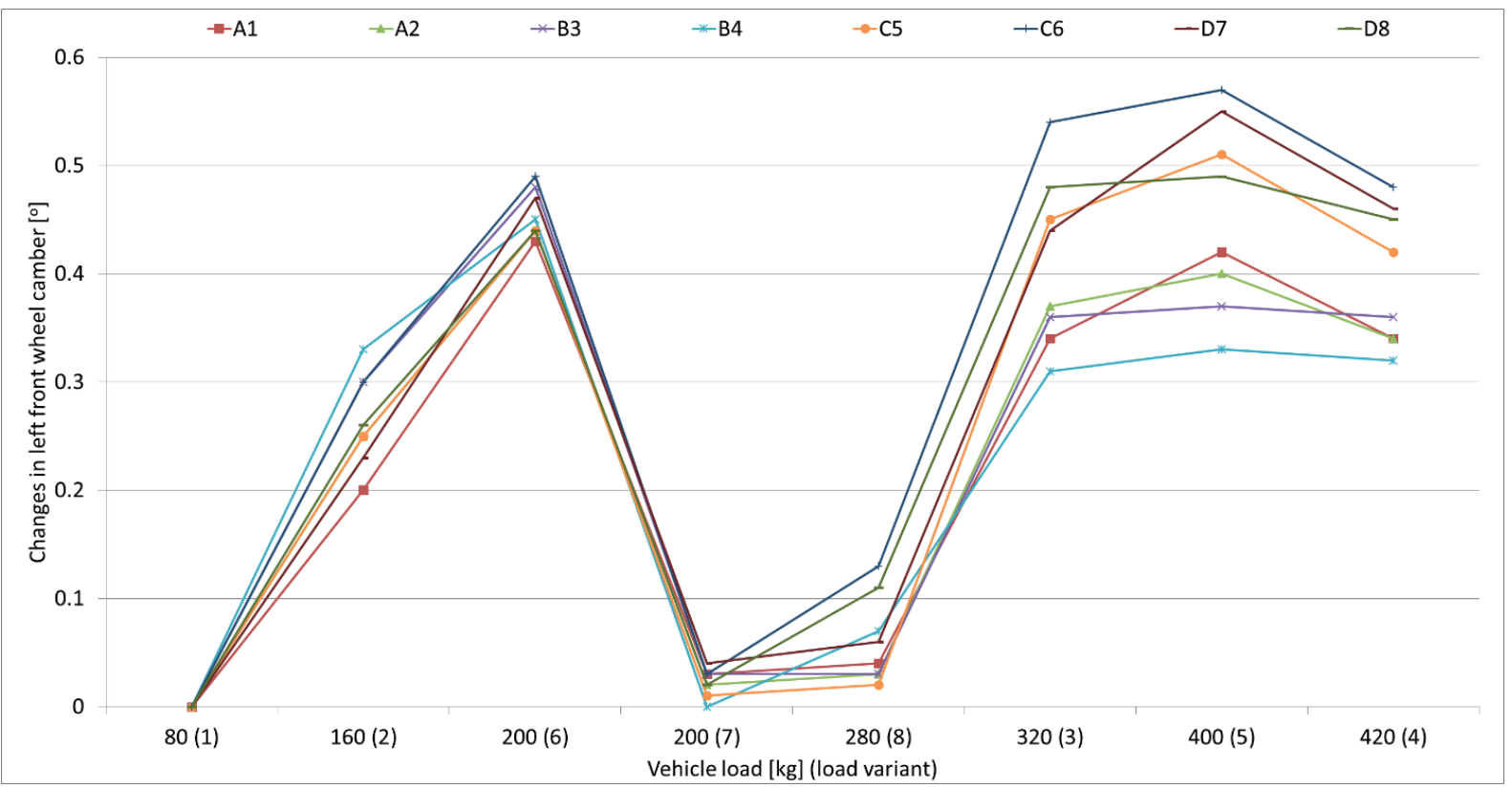

Figure 5 Dependency of changes in the left front wheel camber on the weight distribution

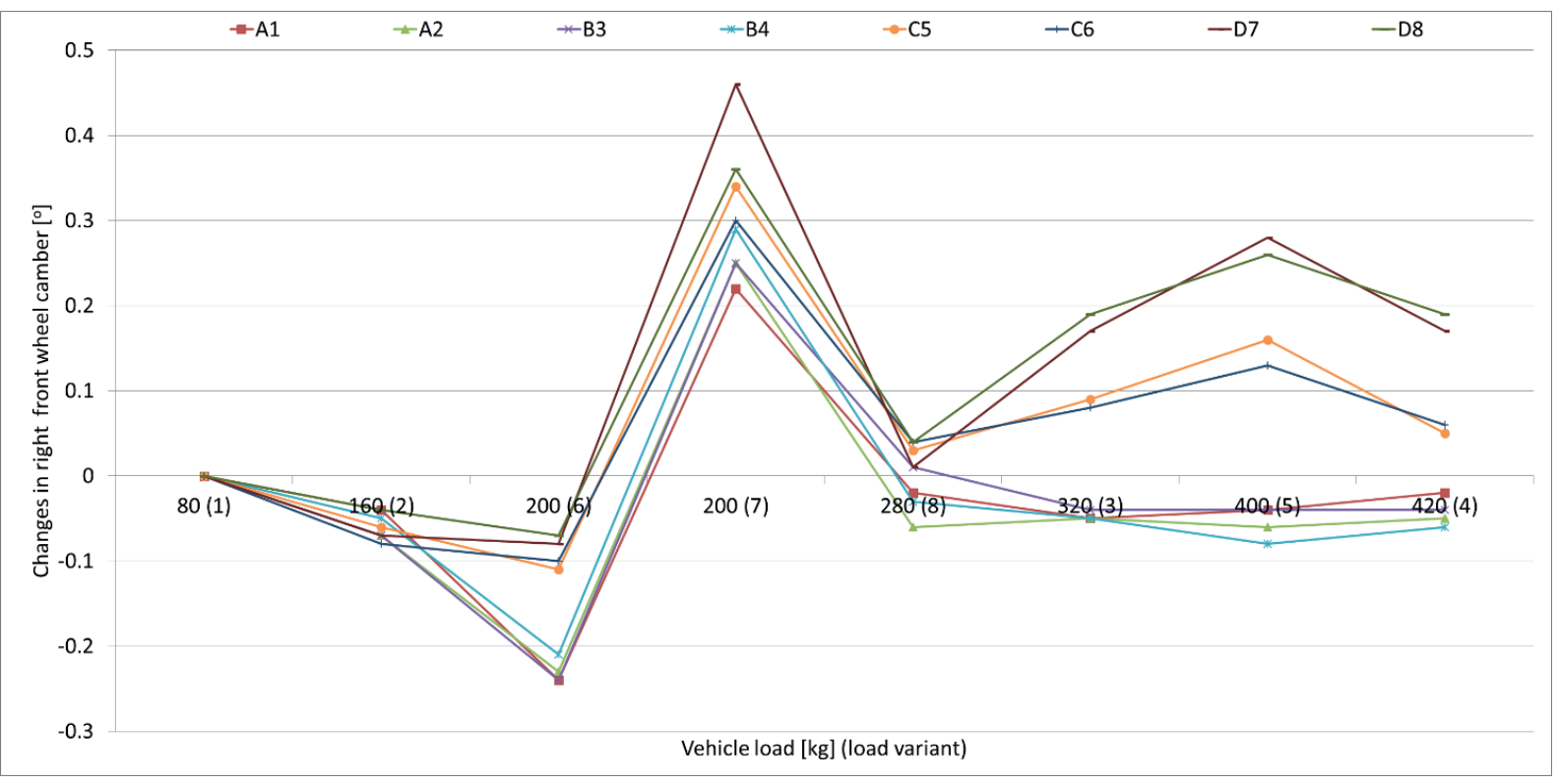

Figure 6 Dependency of changes in the right front wheel camber on the weight distribution

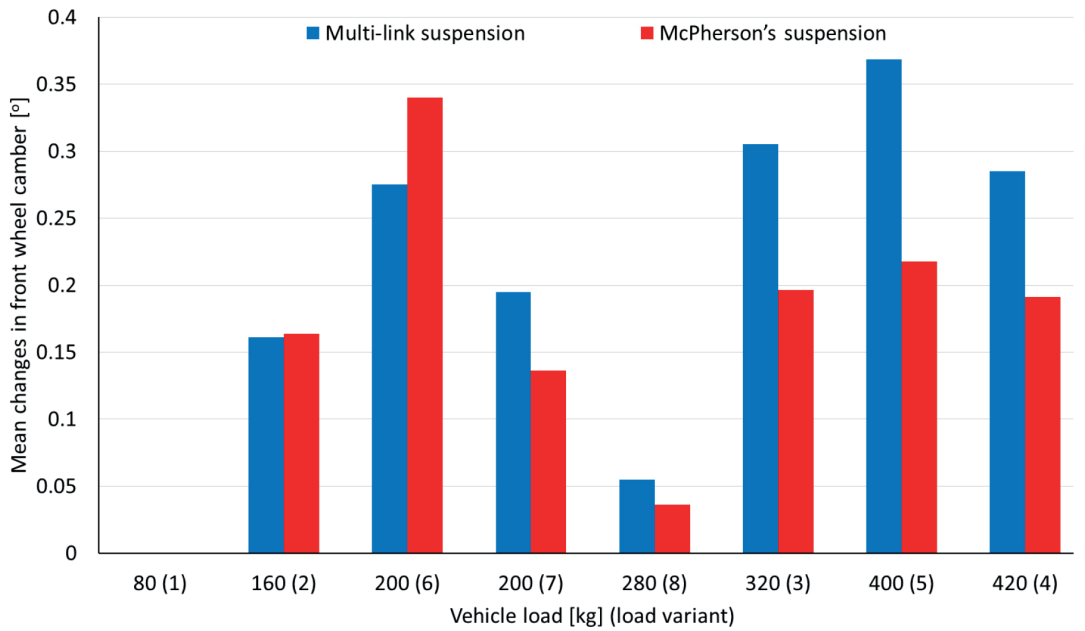

Figure 7 Breakdown in camber changes for the front wheel depending on the suspension type 


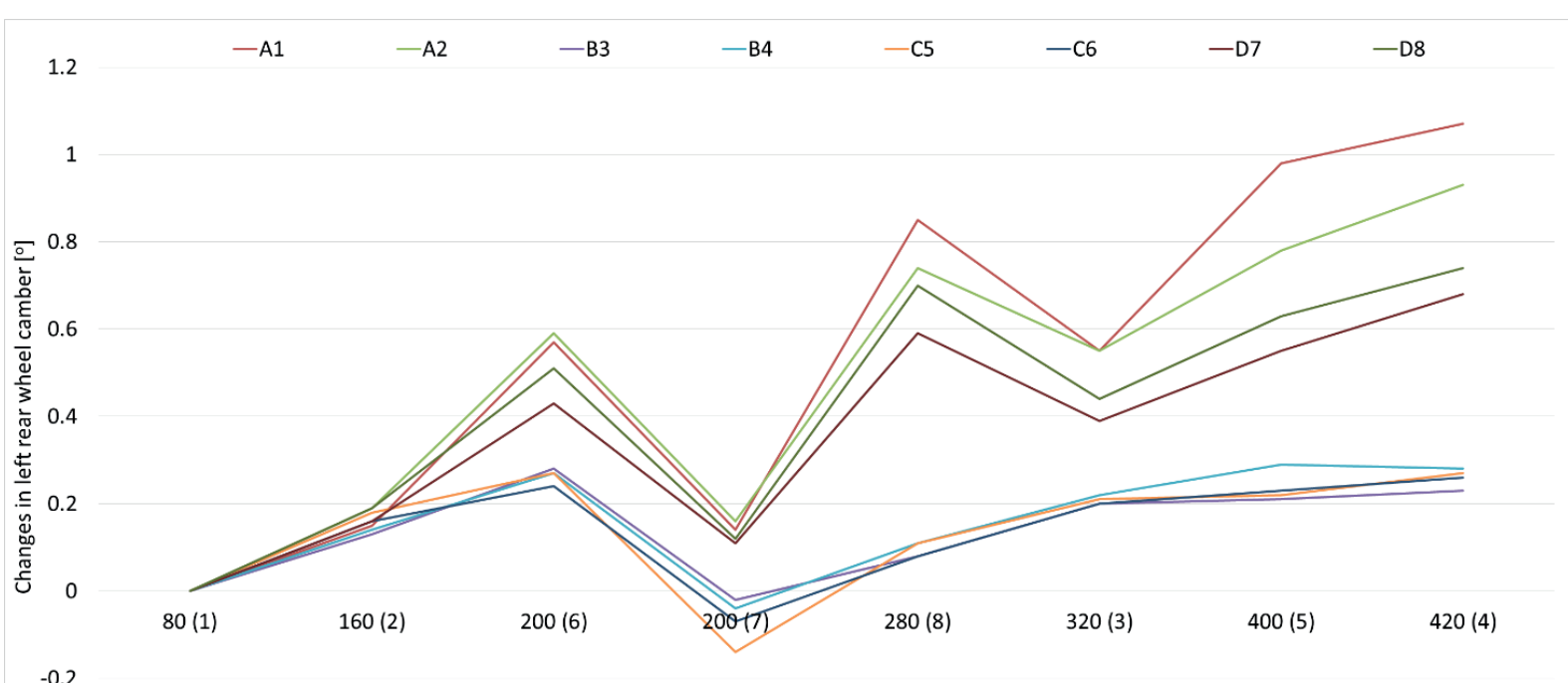

$-0.2$

$-0.4$

Vehicle load [kg] (load variant)

Figure 8 Dependency of changes in the left rear wheel camber on the weight distribution

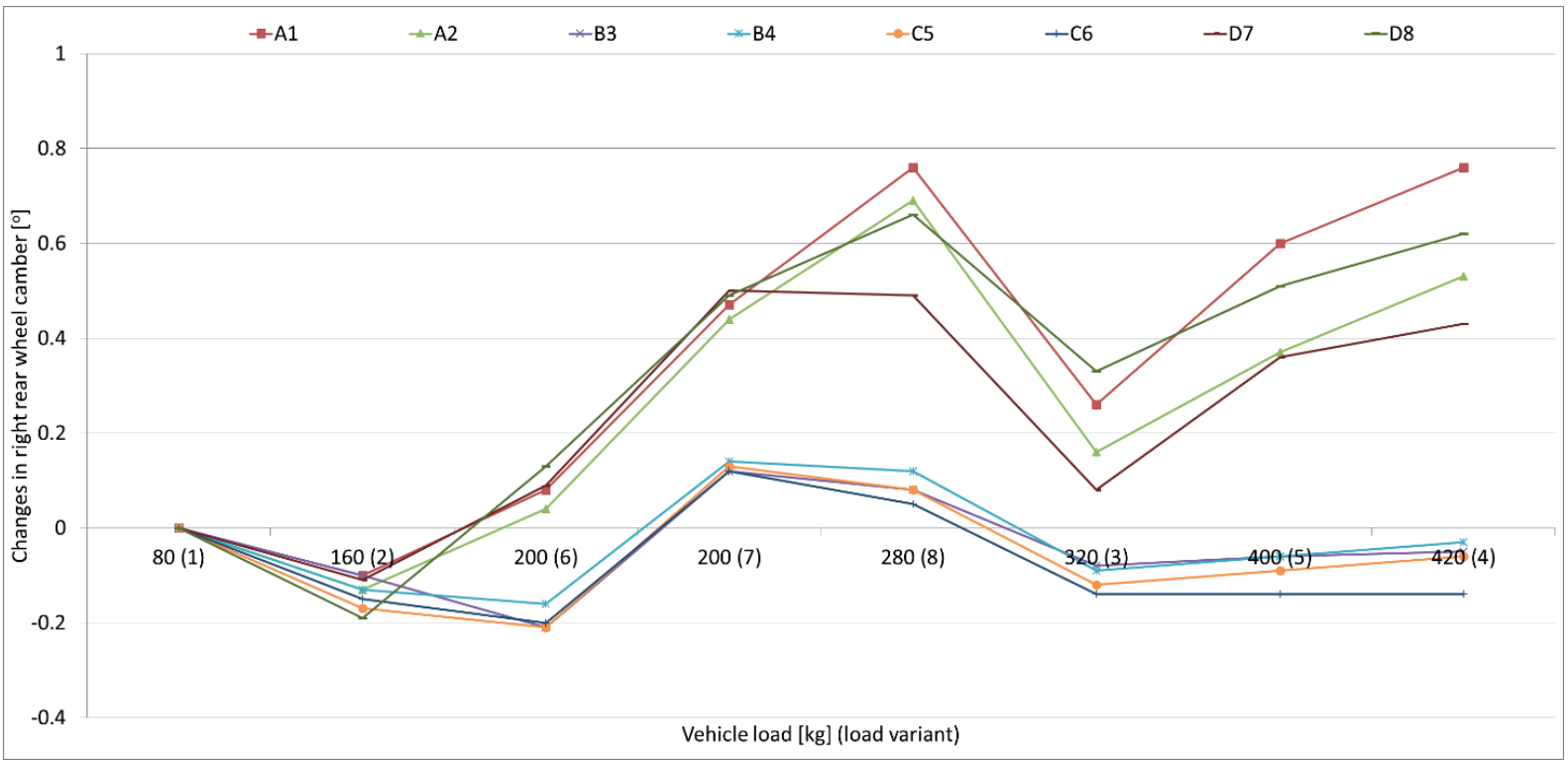

Figure 9 Dependency of changes in the right rear wheel camber on the weight distribution

dimensions. Table 1 presents detailed characteristics of vehicles.

Measurements of geometry of the suspension and steering systems were carried out with the Autoboss A860 computer-laser device (Figure 1a) with an accuracy of 1'. It consisted of a Pc-based control unit with a dedicated piece of software installed and four heads (Figure 1b). They were assembled on individual wheels of the vehicle. During the measurements, the heads communicated wirelessly and transmitted information to the control unit. The Beissbarth STL7000 diagnostic line, equipped with the Micro-Swing 6200 module, was used to measure the load and weight distribution on vehicle axles (Figure 2).

During the preliminary tests, it was verified whether the vehicles had correct geometry of the suspension and steering systems. It was found that none of the tested wheel geometry parameters exceeded the permissible values.

During the basic tests, the wheel geometry parameters were measured, as shown in Figure 3.

During the basic tests, each vehicle was loaded with the same weight placed in the same place. Eight load variants were analysed, as graphically shown in Figure 4. The vehicles were loaded with specially prepared lead bars, which were placed on the front seats, back seat and in the boot.

\section{Analysis of the test results}

The camber of the left front wheel (Figure 5) and the right front wheel (Figure 6) changed significantly with 


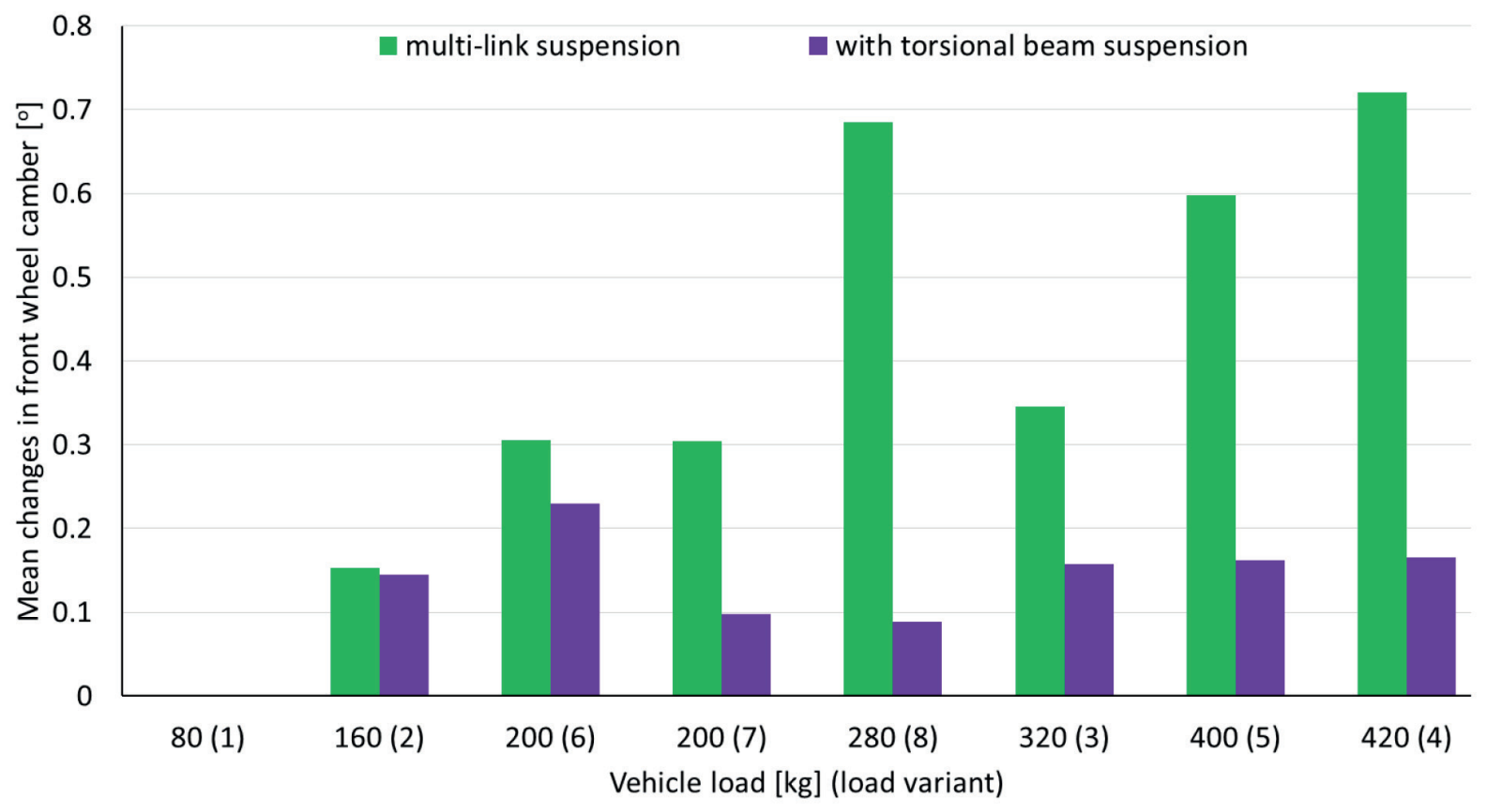

Figure 10 Breakdown in camber changes for rear wheel depending on the suspension type

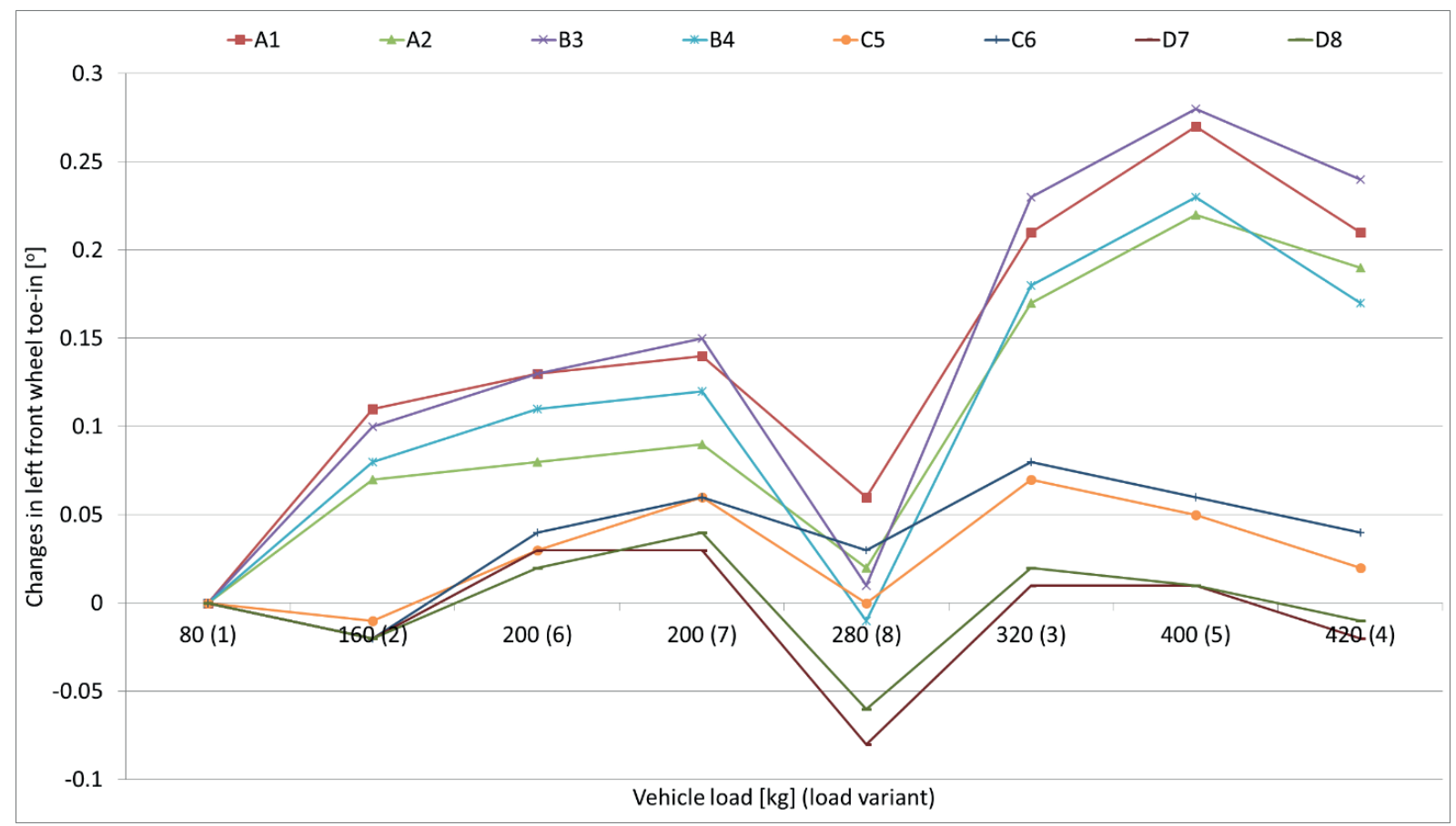

Figure 11 Dependency of changes in the left front wheel toe-in on the weight distribution

changes in the load sizes and load distribution. On the left-hand side, this parameter reached top values in most vehicles for variants with heavy load (320, 400 and 420 $\mathrm{kg}$ ) and symmetrical weight distribution, as well as with asymmetrical weight distribution under relatively low load (200 kg). It was found that in the case of vehicles with multi-link suspension, greater changes for this angle were recorded than in vehicles with McPherson columns. They reached, respectively, $+0.58^{\circ}$ and $+0.4^{\circ}$ with the vehicle loaded with a weight of $400 \mathrm{~kg}$, placed in the passenger cabin. In the case of the front right wheel, the top values were already reached for much lower loads with the whole load being on the left-hand side of a vehicle. Change in the right front wheel camber during the simulation of some load variants recorded large positive and negative values for some of the load variants. For example, when the vehicle was loaded with $200 \mathrm{~kg}$, the large positive values of the front right wheel camber were found, reaching up to $+0.48^{\circ}$. That was also the case when the weight was placed on the driver's seat and on the back seat on the 


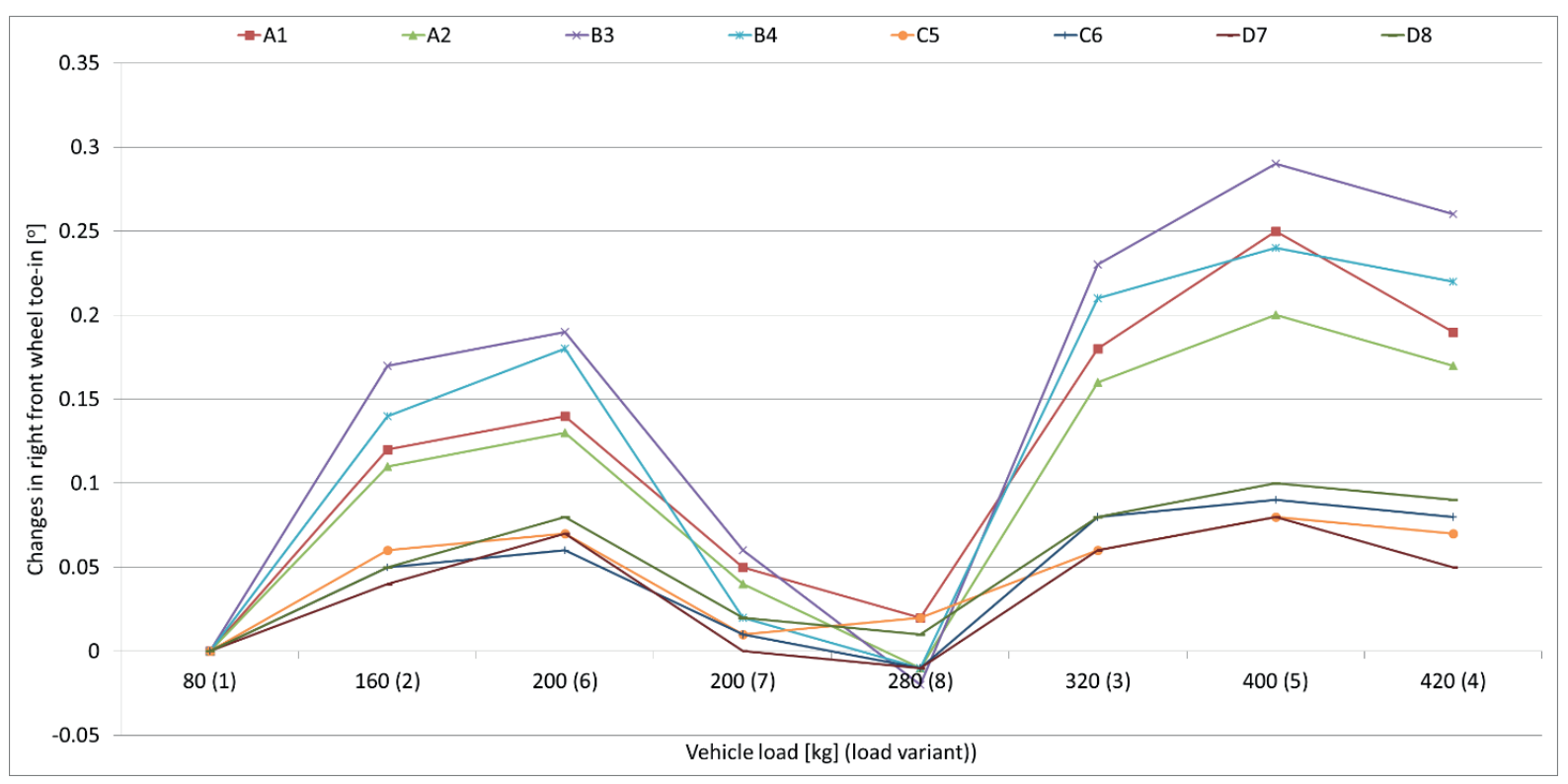

Figure 12 Dependency of changes in the right front wheel toe-in on the weight distribution

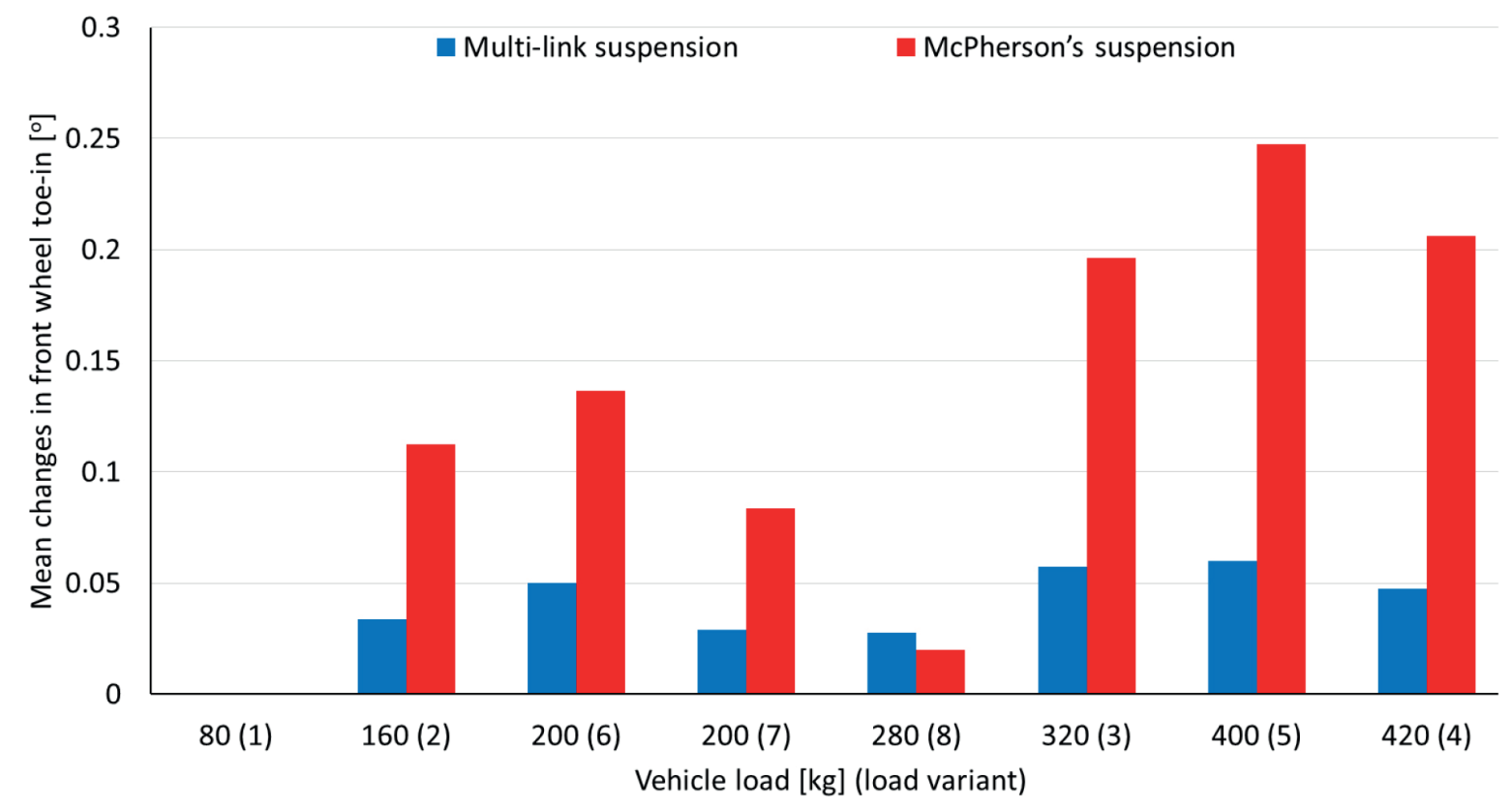

Figure 13 Breakdown in the toe-in changes for the front wheel depending on the suspension type

left-hand side of a vehicle. However, the negative values, reaching $-0.23^{\circ}$, were observed in cars under the same load but applied to the driver's seat and to the back seat on the right-hand side of a vehicle.

In the case of a camber of both front wheels, larger changes depending on the load were observed in cars with multi-link front axle suspension than in cars with the McPherson column (Figure 7). This is fairly beneficial as it improves grip when taking turns. A car with a multi-link suspension better adapts to changing load conditions and varying weight distribution. Better tyre adhesion to the road surface is also observed when driving straight ahead and braking.

In cars with the multi-link rear axle suspension, changes in load entailed significant changes in the left (Figure 8) and right (Figure 9) rear wheel cambers. In vehicles with the relatively simple rear suspension system, consisting of a torsion beam, those changes were much smaller and amounted to a maximum of $+0.28^{\circ}$. For vehicles with multilink suspension, these changes were several times greater and reached up to $+1.07^{\circ}$. In cars with the multi-link rear axle suspension, changes in camber for both rear wheels assumed positive values after loading. On the other hand, in cars with a torsional beam, in most cases, positive values for the left wheel, but negative values for the right wheel were observed. This was related to distribution of weight on specific wheels when loading the vehicle.

In cars with a relatively simple rear axle suspension based on a torsion beam with higher load sizes and symmetrical weight distribution, a change in castor for 


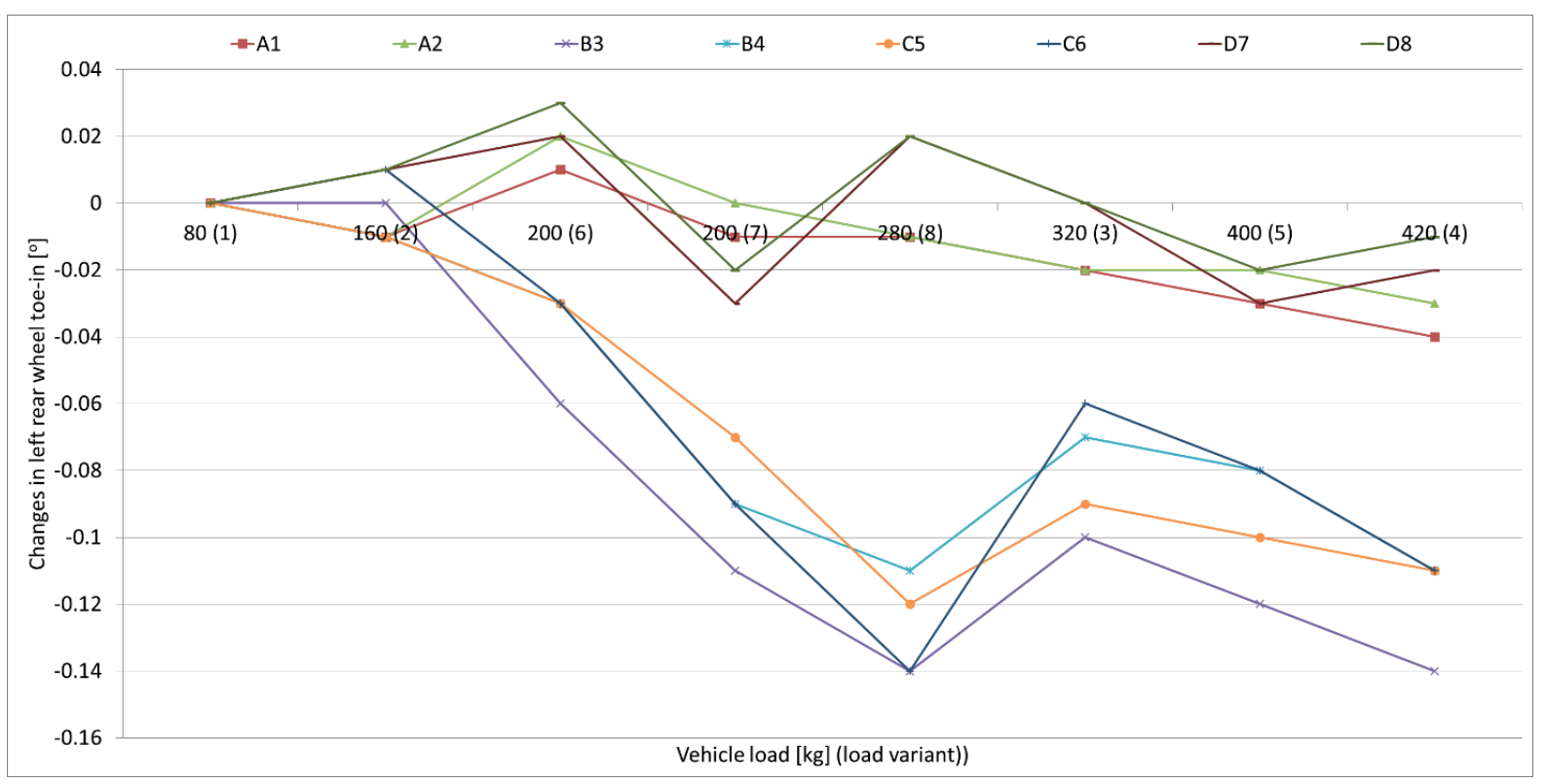

Figure 14 Dependency of changes in the left rear wheel toe-in on the weight distribution

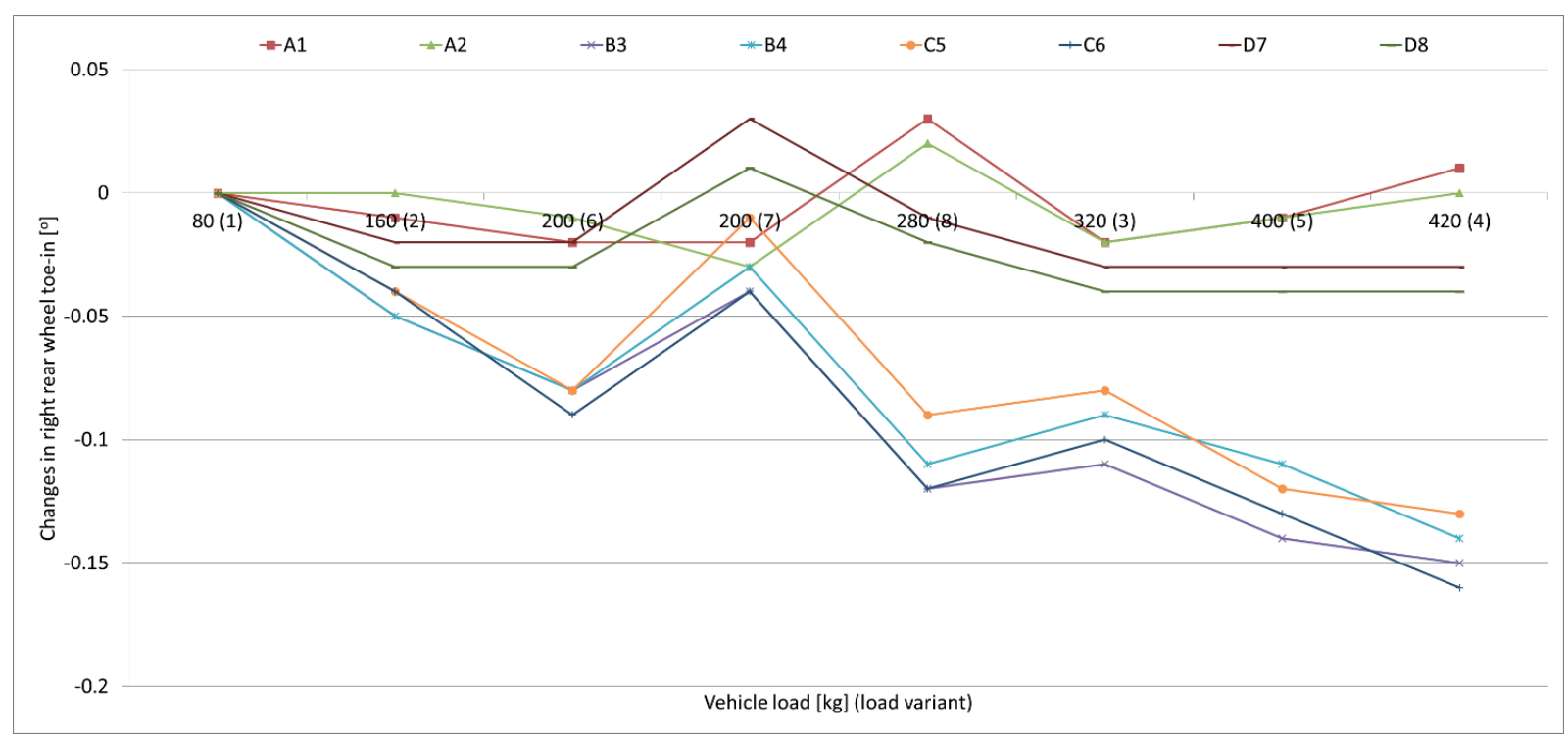

Figure 15 Dependency of changes in the right rear wheel toe-in on the weight distribution

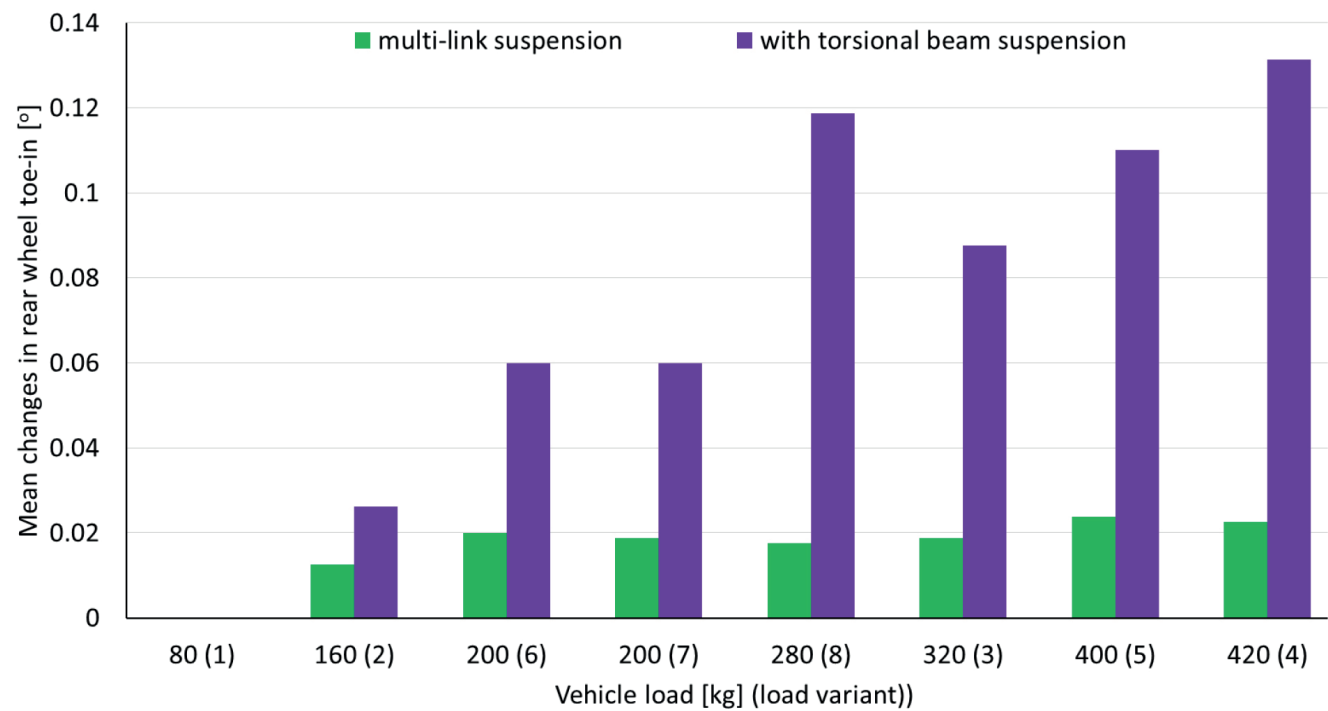

Figure 16 Breakdown in the toe-in changes for the front wheel depending on the suspension type 


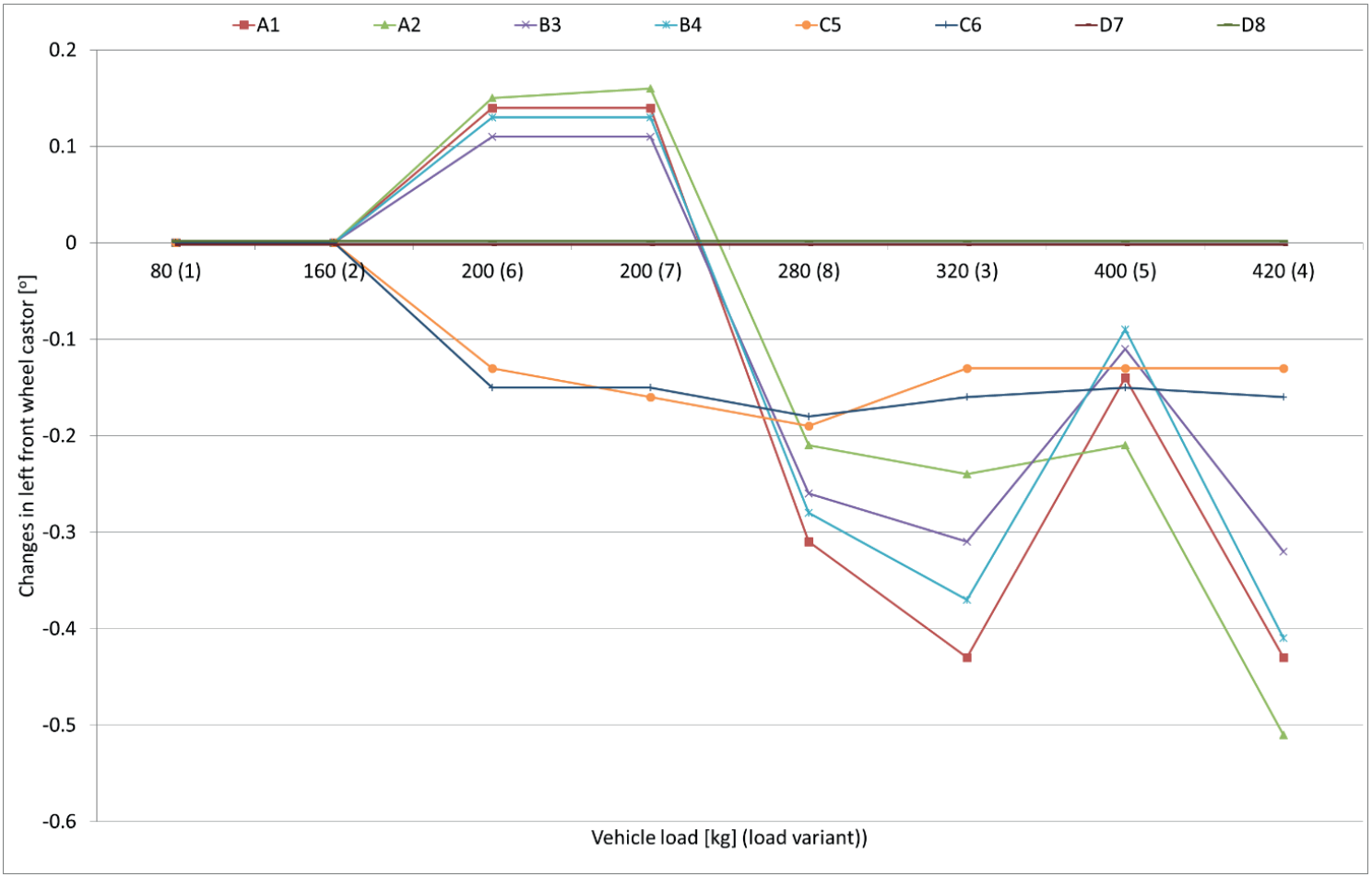

Figure 17 Dependency of changes in the left front wheel castor on the weight distribution

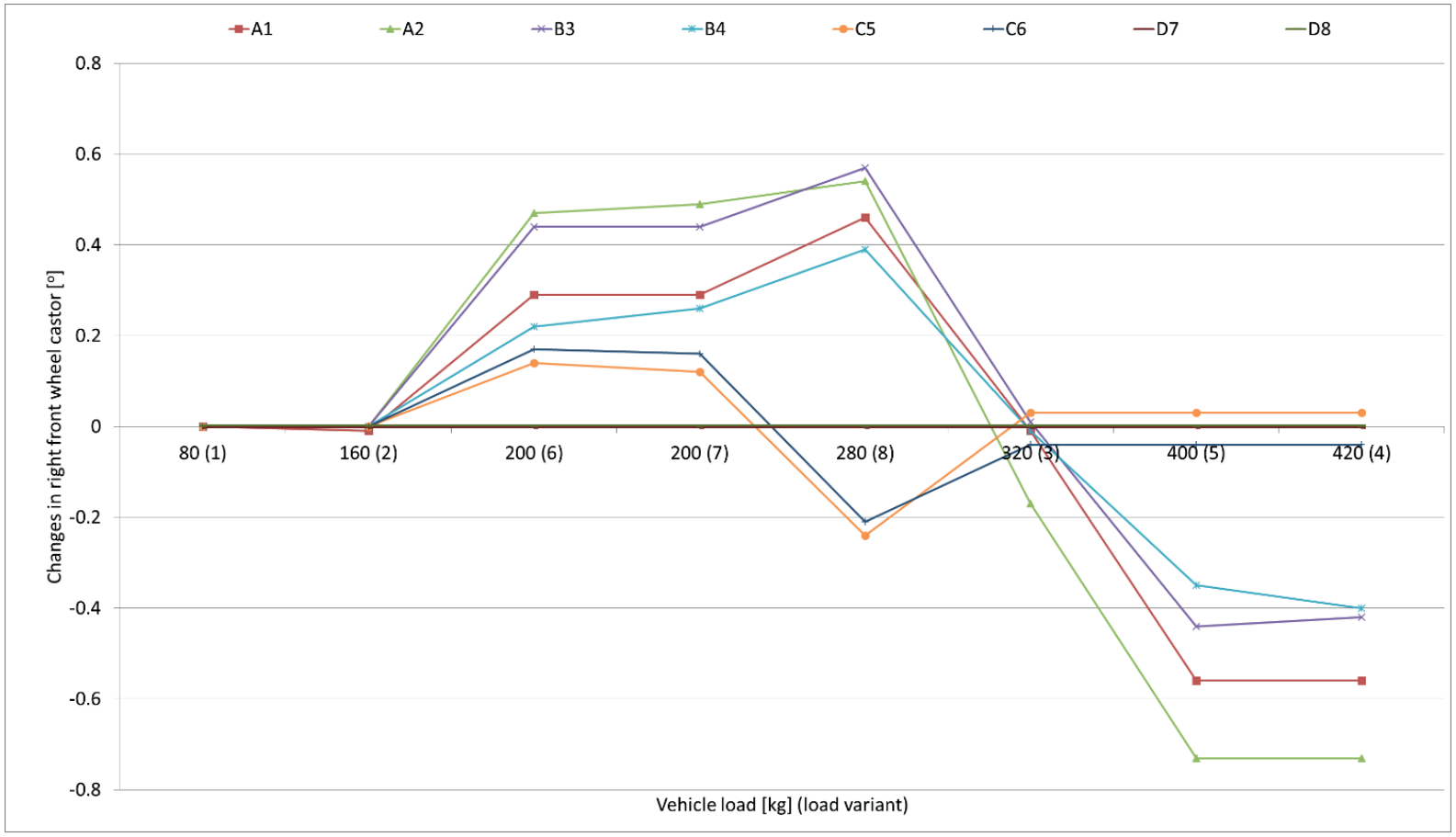

Figure 18 Dependency of changes in the right front wheel castor on the weight distribution

both rear wheels (Figure 10) was only observed to a limited extent, despite significant load (320, 400 and $420 \mathrm{~kg}$ ). Unfortunately, this is an unfavourable feature since, for this reason, the vehicle may drive much worse when loaded. It may lead to wheels not having adequate grip, especially when driving on a curvilinear track.
In each of the tested cars, toe-in for both front wheels changed together with changes in load size and distribution. Much smaller changes occurred in cars with the multilink front axle suspension. For example, changes of the toe-in of the left front wheel (Figure 11) did not exceed $+0.08^{\circ}$. On the other hand, in cars with the McPherson-type 


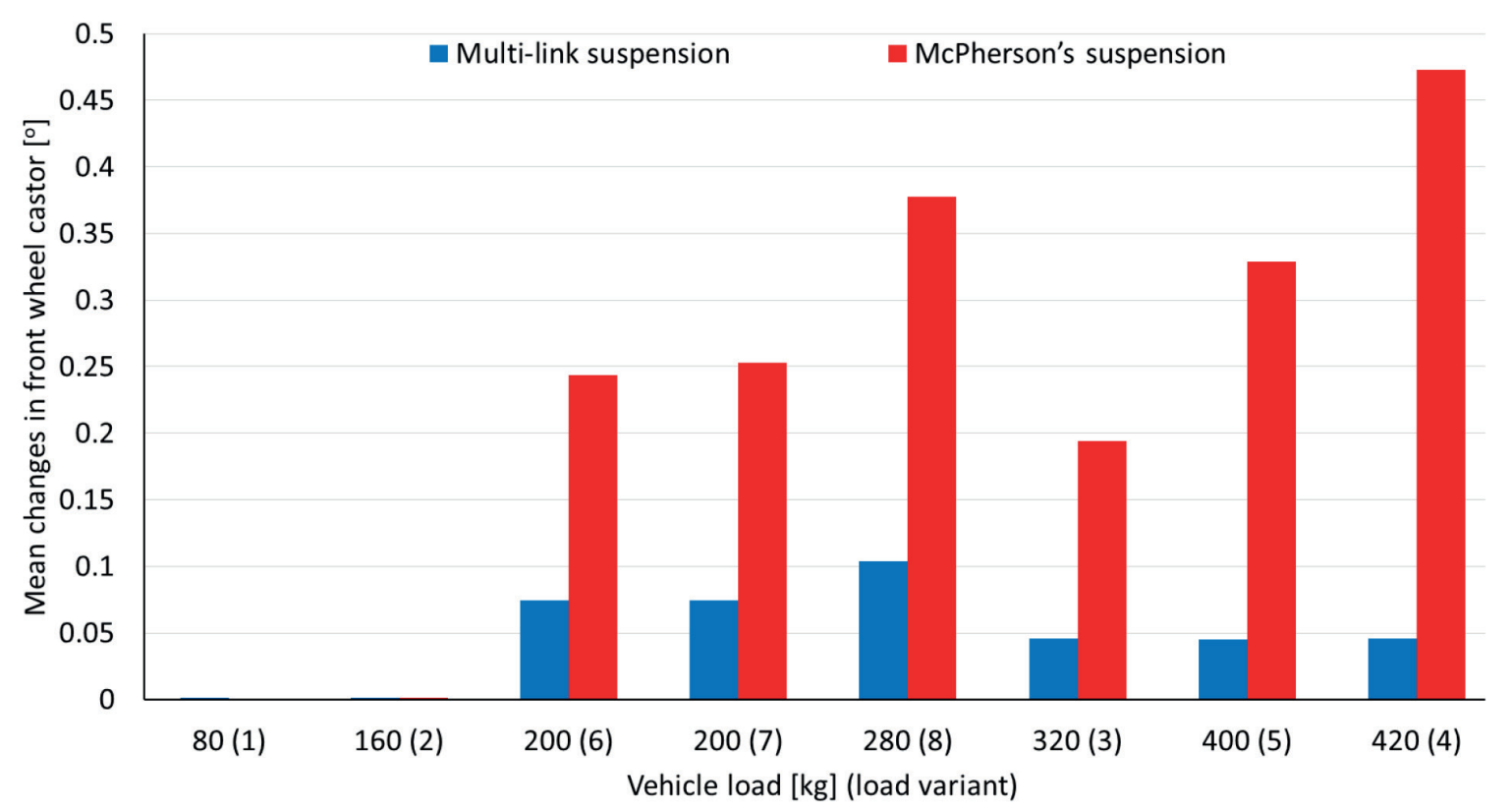

Figure 19 Breakdown in castor changes for the front wheel depending on the suspension type

suspension, greater changes were observed, reaching even $+0.28^{\circ}$ when loaded with $400 \mathrm{~kg}$ placed in the passenger space. In cars with the multi-link suspension, changes in the toe-in took both positive and negative values depending on the load, which is due to the specific design of this type of suspension and better adaptation to changes in load, which positively affects driving. Similar values of changes were obtained for the front right wheel toe-in (Figure 12). Values of this parameter increased with practically every simulated load variant in the all cars. In addition, in the case of this parameter, smaller changes in the toe-in after loading occurred in cars with the multi-link suspension, with a maximum of $+0.1^{\circ}$. In turn, in cars with the McPherson-type suspension, these changes were almost three times greater $\left(+0.29^{\circ}\right)$.

The toe-in determines stability of a vehicle when driving on a straight track, precision of the response when driving on a curvilinear track and e degree of the tyre wear and fuel consumption. Changes in this parameter are strictly dependent on the vehicle load. In cars with the multi-link suspension, changes in the toe-in of the front axle wheels (Figure 13) were less dependent on the size and distribution of the load during the driving.

For the rear axle toe-in, it is also advantageous that changes in this parameter were as small as possible (depending on the load). For the left rear wheel (Figure 14), relatively small variations in the toe-in were observed depending on the load size and distribution in cars with the multi-link rear axle suspension. These changes did not exceed $-0.04^{\circ}$. Much larger changes occurred in vehicles with the torsion beam suspension in the rear axle. In this case, changes were several times greater and reached $-0.14^{\circ}$. Particularly large changes occurred after loading the rear part of a vehicle. This was the load variant no 4 , where a weight of $320 \mathrm{~kg}$ was distributed symmetrically in the passenger cabin and a weight of $100 \mathrm{~kg}$ was additionally placed in the boot and variant no 8 in which, in addition to the driver's own weight, the car was also loaded with a 200 $\mathrm{kg}$ load placed in the boot. In the simulated load variants, changes in the rear right wheel toe-in (Figure 15) were also much smaller in cars with the multi-link suspension. They did not exceed $-0.04^{\circ}$. In cars with the rear axle suspension, based on a torsion beam, particularly large changes in the toe-in were found after loading the vehicle (400 and $420 \mathrm{~kg}$ ). In this case, the toe-in changes of the rear right wheel were up to four times greater and reached $-0.16^{\circ}$.

Similarly, as with the toe-in for the front axle, the rear axle toe-in directly relates to stability of a vehicle when driving on a straight track, as well as to the reaction precision when driving on a curved track. Changes in this parameter are strictly dependent on the vehicle load. In cars with the multi-link suspension, changes in the toe-in of the rear axle wheels after load change (Figure 16) were much smaller, which translates into a smaller impact of the load size and distribution on the vehicle control with this suspension system design.

Analysis of changes in the front left wheel castor (Figure 17) and front right wheel castor (Figure 18) shows that this parameter did not change at all, or changed in a relatively small range (up to $-0.22^{\circ}$ ), in cars with the multilink front axle suspension. On the other hand, in cars with the McPherson-type suspension, the changes depending on the load were much greater and reached even $-0.74^{\circ}$. In some cases, change in castor was positive for both wheels, while in other cases it was negative.

A lack of changes (or minor changes) in castor for both wheels of the front axle (Figure 19), in cars with the multiple-link suspension, together with change in the load distribution and size, are both of a great importance for the vehicle safety. Value of this angle influences the stability of the steering system and contributes to the automatic wheel positioning when driving on a straight track. For the large 
changes in castor with varied load variants, changes in the vehicle stability may affect maintaining the correct driving direction.

\section{Summary}

The suspension systems of many modern passenger cars differ significantly in the type of suspension used for the front and rear axles. Many vehicles still have a relatively simple suspension system of the front axle, based on the McPherson's column and a simple suspension system of the rear axle, based on a torsion beam. When driving cars with such structural solutions, the conditions change depending on the transported load. Type of the suspension system has a significant impact on changes in the wheel geometry parameters.

This study has shown that in all the tested passenger cars, the change in the value and location of the load was accompanied by a change in the wheel geometry parameters. These included toe-in and camber for all the wheels and castor for the front axle wheels. For operation of ae vehicle, it is advantageous when a change in the load size and distribution is accompanied by a greater change in camber. Changes in angle and adjustments to the load are very beneficial as they improve the road adhesion when taking turns. Among the vehicles tested, much larger changes in both the front and rear axle camber were observed in cars with the multi-link suspension systems. Thanks to this, vehicles with multi-link suspension drive can be better controlled and can adapt to changing load conditions and different weight distribution. The better tyre adhesion to the road surface was also observed in curvilinear and straight-line motion, as well as during the braking.

The large changes in the toe-in that were found in cars with relatively simple front axle (McPherson's column) and the rear axle (torsion beam) suspension are unfavourable. This parameter is directly related to stability of a vehicle when driving on a straight track and reaction precision when driving on a curvilinear track. In cars with the multilink suspension, those changes were much smaller, i.e. the vehicle can be driven in a relatively comparable way with varied load sizes and distribution. For the front axle wheels, castor was also analysed. The smaller changes were observed in cars with the multi-link suspension than in cars with the McPherson's suspension. In the former, castor changed relatively little or not at all, so changes in size and distribution do not significantly affect stability of a vehicle or maintain its driving direction.

It was found that cars with the multi-link suspension in both the front and rear axle adapt best to changes in weight and load distribution, thus drive the best under the variable load conditions.

\section{References}

[1] CALVO, J. A., ALVAREZ-CALDAS, C., SAN ROMAN, J. L., COBO, P. Influence of vehicle driving parameters on the noise caused by passenger cars in urban traffic. Transportation Research Part D: Transport and Environment [online]. 2012, 17(7), p. 509-513. ISSN 1361-9209. Available from: https://doi.org/10.1016/j.cub.2016.05.047

[2] CHEN, H., GONG, X., HU, Y. F., LIU, Q. F., GAO, B. Z., GUO, H. Y. Automotive control: the state of the art and perspective. Acta Automatica Sinica [online]. 2013, 39(4), p. 322-346. ISSN 1874-1029. Available from: https://doi.org/10.1016/S1874-1029(13)60033-6

[3] DIONNE, G., MICHAUD, P. C., PINQUET, J. A review of recent theoretical and empirical analyses of asymmetric information in road safety and automobile insurance. Research in Transportation Economics [online]. 2013, 43(1), p. 85-97. ISSN 0739-8859. Available from: https://doi.org/10.1016/j.retrec.2012.12.006

[4] BROUGHTON, J. Car driver casualty rates in Great Britain by type of car. Accident Analysis and Prevention [online]. 2008, 40(4), p. 1543-1552. ISSN 0001-4575. Available from: https://doi.org/10.1016/j.aap.2008.04.002

[5] HELAI, H., HOONG CHOR, C., HAQUE, M. Severity of driver injury and vehicle damage in traffic crashes at intersections: A Bayesian hierarchical analysis. Accident Analysis and Prevention [online]. 2008, 40(1), p. 45-54. ISSN 0001-4575. Available from: https://doi.org/10.1016/j.aap.2007.04.002

[6] KIM, J., RASOULI, S., TIMMERMANS, H. Satisfaction and uncertainty in car-sharing decisions: an integration of hybrid choice and random regret-based models. Transportation Research Part A: Policy and Practice [online]. 2016, 95, p. 13-33. ISSN 1879-2375. Available from: https://doi.org/10.1016/j.tra.2016.11.005

[7] AUST, M. L. Generalization of case studies in road traffic when defining pre-crash scenarios for active safety function evaluation. Accident Analysis and Prevention [online]. 2010, 42(4), p. 1172-1183. ISSN 0001-4575. Available from: https://doi.org/10.1016/j.aap.2010.01.006

[8] BERA, T. K., BHATTACHARYA, K., SAMANTARAY, A. K. Evaluation of antilock braking system with an integrated model of full vehicle system dynamics. Simulation Modelling Practice and Theory [online]. 2011, 19(10), p. 2131-2150. ISSN 1569-190X. Available from: https://doi.org/10.1016/j.simpat.2011.07.002

[9] BOAUAZARA, M., RICHARD, M. J., RAKHEJA, S. Safety and comfort analysis of a 3-D vehicle model with optimal nonlinear active seat suspension. Journal of Terramechanics [online]. 2006, 43(2), p. 97-118. ISSN 0022-4898. Available from: https://doi.org/10.1016/j.jterra.2004.10.003 
[10] MilAnES, V., GONZALEZ, C., NARANJO, J. E., ONIEVA, E., PEDRO, T. D. Electro-hydraulic braking system for autonomous vehicles. International Journal of Automotive Technology [online]. 2010, 11(1), p. 89-95. ISSN 1229-9138. Available from: https://doi.org/10.1007/s12239-010-0012-6

[11] SEPULCRE, M., GOZALVEZ, J., HERNANDEZ, J. Cooperative vehicle-to-vehicle active safety testing under challenging conditions. Transportation Research Part C: Emerging Technologies [online]. 2013, 26, p. 233-255. ISSN 0968-090X. Available from: https://doi.org/10.1016/j.trc.2012.10.003

[12] BERLEMANN, M., MATTHES, A. Positive externalities from active car safety systems. A new justification for car safety regulations. Journal of Policy Modeling [online]. 2014, 36(2), p. 313-329. ISSN 0161-8938. Available from: https://doi.org/10.1016/j.jpolmod.2014.01.004

[13] GONERA, J., NAPIORKOWSKI, J. An analysis of the active safety of a passenger car body during car use. In: 17th International Conference Diagnostics of Machines and Vehicles: proceedings [online]. MATEC Web of Conferences. Vol. 182. 2018. ISSN 2261-236X. Available from: https://doi.org/10.1051/matecconf/201818201022

[14] CIROVIC, V., ALEKSENDRIC, D., SMILJANIC, D. Longitudinal wheel slip control using dynamic neural networks. Mechatronics [online]. 2013, 23(1), p. 135-146. ISSN 0957-4158. Available from: https://doi.org/10.1016/j. mechatronics.2012.11.007

[15] HABIBOVIC, A., DAVIDSSON, J. Causation mechanisms in car-to-vulnerable road user crashes: Implications for active safety systems. Accident Analysis and Prevention [online]. 2012, 49, p. 493-500. ISSN 1879-2057. Available from: https://doi.org/10.1016/j.aap.2012.03.022

[16] AGUILAR, J. J., SANZ, M., GUILLOMIA, D., LOPE, M., BUENO, I. Analysis, characterization and accuracy improvement of optical coordinate measurement systems for car body assembly quality control. International Journal Advanced Manufacturing Technology [online]. 2006, 30(11), p. 1174-1190. ISSN 0268-3768. Available from: https://doi.org/10.1007/ s00170-005-0143-5

[17] KONIECZNY, L. Application of vibratory methods for assessment of technical condition of mechanical and hydropneumatic automotive suspension systems / Wykorzystanie metod drganiowych w ocenie stanu technicznego mechanicznych i hydropneumatycznych zawieszen pojazdow samochodowych (in Polish). Gliwice: Wydawnictwo Politechniki Slaskiej, 2015. ISBN 9788378803256.

[18] GONERA, J., NAPIORKOWSKI, J. Model for forecasting the geometry of the floor panel of a passenger car during its operation. Eksploatacja i Niezawodnosc - Maintenance and Reliability [online]. 2018, 20(4), p. 689-695. ISSN 1507-2711. Available from: http://dx.doi.org/10.17531/ein.2018.4.20

[19] GONERA, J., NAPIORKOWSKI, J. Effect of the mileage of a passenger car on changes in its body geometry. In: The 18th International Conference on Positron Annihilation AIP 2018: proceedings [online]. AIP Conference Proceedings. Vol. 1946. Iss. 1. ISSN 1551-7616, 020011. Available from: https://doi.org/10.1063/1.5030315

[20] WALLENTOWITZ, H. Virtual vehicle development - networks as prerequisites for problem solving. success in networks / Virtuelle Fahrzeugentwicklung - Netzwerkeals Voraussetzungenzur Problemlosung. Erfolg in Netzwerken (in German). Berlin: Springer - Verlag, 2002. ISBN 9783642628535.

[21] BAE, S., LEE, J. M., CHOI, W. J., YUN, J. R., TAK, T. O. Axiomatic approach to the kinematic design of an automotive suspension system with the McPherson strut type. International Journal of Vehicle Design [online]. 2003, 31(1). ISSN 1741-5314. Available from: https://doi.org/10.1504/IJVD.2003.002047

[22] SHAO, X., NAGHDY, F., DU, H., QIN, Y. Coupling effect between road excitation and an in-wheel switched reluctance motor on vehicle ride comfort and active suspension control. Journal of Sound and Vibration [online]. 2018, 443, p. 683-702. ISSN 0022-460X. Available from: https://doi.org/10.1016/j.jsv.2018.12.012

[23] VIDYA, V., DHARMANA, M. M. Model reference based intelligent control of an active suspension system for vehicles. In: International Conference on Circuit, Power and Computing Technologies ICCPCT 2017: proceedings [online]. IEEE. 2017. ISBN 978-1-5090-4967-7. Available from: https://doi.org/10.1109/ICCPCT.2017.8074362

[24] DURMAZ, B. E., KACMAZ, B., MUTLU, I.; SOYLEMEZ, M. T. Implementation and comparison of LQR-MPC on active suspension system. In: 10th International Conference on Electrical and Electronics Engineering ELECO 2017: proceedings. 2017. ISBN 978-605-01-1134-7.

[25] HYNIOVA, K. One-quarter-car active suspension model verification. In: The 2016 International Conference Applied Mathematics, Computational Science and Systems: proceedings [online]. ITM Web of Conferences. Vol. 9. 2017. ISSN 2271-2097. Available from: https://doi.org/10.1051/itmconf/20170903003

[26] SHI, Q., PENG, C., CHEN, Y., HE, J. Robust kinematics design of MacPherson suspension based on a double-loop multiobjective particle swarm optimization algorithm. Proceedings of the Institution of Mechanical Engineers Part D: Journal of Automobile Engineering [online]. 2019. ISSN 0954-4070. Available from: https://doi.org/10.1177/0954407018821556

[27] SHIM, T., VELUSAMY, P. C. Suspension design and dynamic analysis of a lightweight vehicle. International Journal of Vehicle Design [online]. 2007, 43(1-4). ISSN 0143-3369. Available from: https://doi.org/10.1504/IJVD.2007.012307

[28] CHEN B., LIU Y., SHI W. Suspension optimization design and virtual prototype simulation analysis of FSAE racing car. Journal of Physics Conference Series. 2019, 1176(5), 052084. ISSN 1742-6588. 